\title{
Financial Inclusion as a Catalyst for Poverty Reduction in Nigeria
}

\author{
*Akeem Abimbola, Felicia O. Olokoyo, Opeyemi Babalola, Elemide Farouk
}

Banking and Finance Department, Covenant University, Ota, Ogun State.

\begin{abstract}
Financial inclusion which can be explained as access to formal financial services such as credit, savings and insurance opportunities is still very vague in developing countries such as Nigeria where there is high level of poverty. The country has a large number of 'unbanked' people whose business activities are not captured in the country's economic reports. These 'unbanked' populaces are illiterates who are either unemployed or under-employed and lack access to financial services and information and are totally excluded in the financial ecosystem and market. Hence, this paper examines the role of financial inclusion in the reduction of poverty in Nigeria. It examines the roles of government and financial institutions and the use of various mobile initiatives such as mobile banking, mobile money, agent banking etc. as financial inclusion tools to stimulate poverty reduction. Time series analysis on data obtained from secondary sources between the periods of 1992 and 2016 was adopted and the paper covered financial inclusion as it relates to unbanked people in Nigeria. The paper found out that majority of the 'unbanked' in Nigeria are low income people who do not have access to financial services and information on financial inclusion. While few are timid on the need to use a bank, many them are willing to use banking services and believe the availability of these services will help improve their economic condition. The paper therefore recommends that the banks should be encouraged to continue to take advantage of all the financial inclusion policies of the government in mobilizing funds from the informal sector into the banking system. This can be best done by increasing the number of customers within the financial system as a tool for encouraging financial inclusion and stimulating the economy and thereby reducing poverty in the country.
\end{abstract}

Keywords: Financial Inclusion, Financial exclusion, 'unbanked', unemployment, poverty.

\section{Introduction}

Financial inclusion globally has been recognized among governments, researchers and economic observers as an important tool for poverty reduction, employment generation, wealth creation and improving welfare and standard of living of people and in turn economic development. The concept has gained momentum in recent times because of its now obvious impact on poverty alleviation which is key to the economic growth of the country. This is due to the realization by the government that as more people enter the financial system, the lesser the amount of money left outside the system which can help to boost investment in the economy. Umar (2013) opined that no economy can grow on the whole if large parts of its population are not covered by the financial system as they are the real economic pillars. Martinez (2011) also noted that access to financial services is a useful tool that the government can employ in stimulating and accelerating economic growth with efficient distribution of available resources, thereby leading to decreased capital cost.

There are diverse opinions on the meaning of financial inclusion. The Global Partnership for Financial Inclusion and Alliance for Financial Inclusion have pushed the belief that financial inclusion is achieved and defined differently in each distinctive circumstance (IFC Bulletin, 2018). Financial inclusion for the purpose of this study will be adopted to mean the introduction of individuals and small enterprises who are hitherto not within the financial system and do not have access to basic, affordable and appropriate formal financial services that meet their needs.

Formal financial services can be defined along several dimensions, including geographic access (i.e. proximity to a financial service provider) and socio-economic access (i.e. absence of prohibitive fees and 
documentation requirements) (Thorsten, 2016). Financial inclusion incorporates the concept of microfinance, which according to Thorsten (2016) refers to the provision of products to specific groups at the lower end of the market, using specific delivery techniques and institutions. The challenge of most African economies is how to move funds from informal to formal economy.

Mbutor and Uba (2013) also described financial inclusion as a state where a person is able to access financial services from the formal financial system at an affordable cost. Leyshon \& Thrift (1995) also described financial inclusion as a state where people have easy access to proper and relevant financial products and services in effectively managing their financial resources. Nigeria currently has a population of over 200million with about $60 \%$ of this within the adult population. However, the country only has 80 million total Bank customers with only $25 \%$ of this confirmed on the Bank's verification system so far with strong indication that a reasonable number of the yet to be verified customers are duplications (CBN reports). This is an indication that the level of financial inclusion in Nigeria is still very low. The bulk of the active Bank customers are located in the urban centers where economic activities are booming. Rural communities continue to face financial exclusion with a large number of their dwellers financially excluded (Ajide, 2014). This confirms that there is a relationship between the level of financial inclusion and economic activities with respect to welfare of the people in a community. There is evidence that people who are financially included tend to be more productive, consume more and invest more (Beck et al., 2004). Because financial inclusion has a great influence on economic and social impact, it has taken centre stage in the deliberations of policy makers in the efforts to alleviate poverty. Sanusi (2011) points out that the increase in the number of people being financially excluded from the formal financial system is responsible for the high poverty level in Nigeria. He suggested that financial inclusion should be promoted such that it is able to increase economic activities, grow GDP and stabilize the economy. According to Mckinsey (2014), Nigerians who have access to financial services are about $21 \%$ while South Africa has about $46 \%$ financial inclusion rate. Also, the World Bank report of 2014 also shows that while $2 \%$ of Nigerians have access to loans, South African had about 32\% of its population having access to formal credit. In another study by Cyn-Young \& Ragelio (2015), Nigeria ranked 135th out of the 176 countries evaluated on financial inclusion.

117 countries adopted a declaration and program of actions which included commitments to eradicate "absolute" and reduce "overall" poverty level after the Social Development in Copenhagen in 1995, (Gordon, 2005). Poverty has been severally defined by different authors and studies and there is no one applicable definition for the concept of poverty. According to investopedia, it is a situation where people are unable to live within the minimum acceptable standards because of the lack of basic amenities including financial services. In the study of Ajakaiye (1998), he described poverty as a state where a person is unable to meet his or her basic needs like water, food, shelter, education and including non-essentials like identity etc. Latifee (2003) in another study recognized that poverty may be due to a person's lack of social, economic and political privileges due to lack of income, basic human capacities, institutional defense, and sometimes all of these combined. Poverty can be defined as the state of being extremely poor. Gordon (2005) noted UN to have defined poverty as a condition characterized by severe deprivation of basic human needs, including food, safe drinking water, sanitation facilities, health, shelter, education and information. It depends not only on income but also on access to services. The World Bank Organization also describes poverty in this way:

"Poverty is hunger. Poverty is lack of shelter. Poverty is being sick and not being able to see a doctor. Poverty is not having access to school and not knowing how to read. Poverty is not having a job, is fear for the future, living one day at a time.

Poverty has many faces, changing from place to place and across time, and has been described in many ways. Most often, poverty is a situation people want to escape. So poverty is a call to action -for the poor and the wealthy alike -- a call to change the world so that many more may have enough to eat, adequate shelter, access to education and health, protection from violence, and a voice in what happens in their communities."

Poverty is often defined on a family basis rather than an individual basis. Economists often seek to identify the families whose economic position (defined as command over resources) falls below some minimally 
acceptance level. Similarly, the international standard of extreme poverty is set to the possession of less than $1 \$$ a day (Okoye et al, 2016).

The concept of poverty has been a major highlight of discourse in literature over the years and the government has over the years also rolled out several approaches and policies in its attempt to alleviate and reduce the menace of poverty within the country. From the Operation Feed the Nation campaign of President Obasanjo to the Green Revolution introduced by the administration of President Shagari to the Better Life scheme of Babangida down to the SUREP program of the Goodluck Jonathan administration and finally to the Mpower program of the current administration, all aimed at improving the standard of living of the people.

Despite all of the efforts of governments globally at alleviating poverty, it continues to be a major problem across the world. No nation in the world can be said to be totally free from poverty even though the extent of it's ravish are in different quantum depending on the level of development in each nation. Poverty by itself is very unique and complex to understand and is more prominent in underdeveloped economies among which is Nigeria (Okoye et al, 2016). Nigeria is blessed with a lot of human and material resources with a large number of it being raw materials, but the country is yet to tap into the potentials of these resources in improving the living standard of its populace as a large number of them are still ravaging in poverty.

Financial inclusion can contribute to poverty reduction, economic and social development, and financial stability (United Nations Conference on Trade and Development, 2014). The high level of impact financial inclusion has had in developed countries continues to be a motivating factor for its adoption in developing countries in the fight against poverty. The United Nation estimates that about 3 billion people are still financially excluded population in the world and therefore do not have access to formal financial services. These people do not have bank accounts; they cannot access credit nor get insurance and do not have any means of saving neither can they receive social benefits. However, it is becoming increasingly difficult to financially include people living in rural suburbs due to the unavailability of financial service providers in these locations. Banks are usually uninterested in giving access to the hundreds of millions of men and women (all over the world) who are presently excluded from financial services who could provide a large depository of savings, investable funds, investments and therefore can help with global wealth generation (Kama, 2013). Financial inclusion is considered to be one of the sources of poverty reduction, included in the Millennium goals: Eradicate extreme poverty and hunger. This issue is not just related to charity: market opportunities among the poorest are underestimated and should be explored by multinational companies, as there are evidences that multinationals that provide services to the bottom-of-the-pyramid are successfully doing business in developing countries (Prahalad \& Hammond, 2002).

Financial inclusion has globally become an important part of the development agenda that aims at reducing poverty levels further. It is therefore critical to understand what works and what does not work in financial inclusion (Thorsten, 2016). In Kenya for instance, mobile money was very effective in the financial inclusion strategy of the government in that country with over $80 \%$ of the adult population using the service. This has not worked in Nigeria as it has been quite difficult for the mobile money service providers to penetrate the Nigerian market. The worrisome reality is that most African economies including Nigeria are being run by a small fraction of the citizens, as such, any economy where the majority of the citizens are financially excluded and unbanked, the implication might be a threat to the economy (Okaro 2016). A wellfunctioning and inclusive financial system is linked to a faster and equitable growth; thus, it is characterized by the diversity of financial services which leads to wealth creation (Aduda \& Kalunda, 2012). Sanusi (2011) had attributed the rise in poverty level in Nigeria to the challenges of financial exclusion. According to him, achieving optimal level of financial inclusion in Nigeria means empowering 70.0 per cent of the population living below poverty level, and this would boost growth and development. It is believed that when the poor are financially included, it increases their ability to create wealth and as such increases their living condition and hence alleviates poverty.

There is no one cause of poverty, and the results of it are different in every case. Poverty varies considerably depending on the situation. Feeling poor in Canada is different from living in poverty in Russia or Zimbabwe. The differences between rich and poor within the borders of a country can also be great. The 
poor in developing countries find expensive and difficult to save, few banks are interest in their savings and in providing services for them. As a result, those people cannot accumulate money to invest. (Khavul \& Bruton, 2012). Poverty reduction is considered one of the main factors behind the development of a country (Essegbey \& Frempong, 2011). CBN (2013) also noted that the global financial inclusion average level is below 50\% which means more than half of the average numbers of adults in the world are financially excluded; meaning they do not have access to financial services. These challenges are more prominent in developing economies and the third world with a large number of these people living in African countries in particular, such that attaining financial inclusiveness is now a global test (Ardic et al, 2011). Globally in order to remove barriers such as age, gender, irregular income, education etc, a global target has now been set to ensure irrespective of any barriers, financial services are being enjoyed by billions of people all over the world in order to reduce poverty and improve standard of living.

Sanusi, (2011) linked financial exclusion to the continued upspring of poverty in Nigeria. He opined that in order to maximize financial inclusion in the country, the government must make efforts to financially include and empower $70 \%$ of the presently financially excluded population. He noted that their inclusion has the potential to accelerate economic activities thereby enhancing economic development and hence reduce poverty.

This study intends to explore the empirical relationship between financial inclusion and poverty reduction as a contribution to the ongoing discuss in relevant studies. It intends to review how financial inclusion can be used to improve the living standard of people. Khan (2011) says that the pursuit of financial inclusion is not just a policy option but is compulsory; it is about the various workable strategies to accelerate its rate of reach and deepen the acceptability of such policies and strategies. The remaining part of this study will have the literature review follow on this introduction where the author will evaluate existing literature and standpoints on poverty alleviation and financial inclusion. The author intends to identify gaps in literatures that the study will be filling. The next session will focus on the research design and methodology used with theoretical supports and relevant model. The last segment will present the result analysis while conclusion and recommendation is made at the concluding session.

\section{Literature Review \\ Conceptual Framework of Financial Inclusion}

From the definition of financial inclusion by the Rangarajan Committee (2008), financial inclusion can be summarized to be the process by which financial services (credit inclusive) are made available to people within the economic system that are not privileged to these services due to low income and inaccessibility in a timely and cost-effective manner. Mohan (2006) also described the concept of financial inclusion as a situation where certain segment of the populace access who hitherto lacked access to the financial system are gradually integrated into it through the provision of low - cost, safe and fair financial products and services from mainstream providers. Ajide (2014) describes financial inclusion as the process of delivering the financial system of a country to its people. Sarma (2008) in her own study described it as the process of ensuring easy access, affordable and convenient use of formal financial services. Aduda \& Kalunda (2012) also regarded financial inclusion as the process service provider adopt in making available various financial services, at an affordable price, in a timely manner and accessible to all the members of the society. Financial inclusion is a process, which means it is an ongoing activity. It is obvious that all literatures although might describe it differently but have all agreed that financial inclusion is the effort being made in on boarding people on to the financial system by making financial services available to all especially the low income and rural dwellers. Leeladhar (2006) summarized financial inclusion as the process of delivering to low income and disadvantaged groups banking services at an in a timely and affordably way.

In discussing the concept of financial inclusion, it is very important to also review the concept of financial exclusion. This is because financial inclusion is the process of correcting financial exclusion problems which entails factors that prevents individuals and other groups from having access to the formal financial system. Mohan (2006) noted that financial exclusion implies that some parts of the societal circle do not have access to safe fair and affordable financial products and services from formal financial service providers. Kama \& Adigun (2013) also described financial exclusion as a situation where formal financial products and services are inaccessible by individual, household or group. These individuals and groups are 
said to be financially excluded and the process of bringing them within the financial service net is what is understood to be financial inclusion. Financial exclusion can be voluntary or involuntary. World Bank (2004) describes voluntary exclusion as a situation where the persons or firms decide based on their personal, cultural or religious belief not to use financial services. Involuntary exclusion on the other hand as explained by Cyn -Young \& Rogalio (2015) often results from inadequate income, proximity issues, high risk profile or discriminatory market tendencies. The concept of financial inclusion was adopted by Nigeria after the introduction of the structural adjustment program (SAP) by former President Babangida in 1986.

\section{Conceptual Framework of Poverty}

The word poverty coined from the word pauper, a Latin word for poor is a largely used concept worldwide and has been recognized as a global problem. World Bank (1997) described poverty as a condition of hunger, no shelter, poor health, no education, not being able to read or write, no jobs, high infant/child mortality and living in constant fear. In the view of Ajakaiye (1998), poverty depicts where a person is unable to access basic needs such as food, shelter, clothing, education and lacks an identity. Aku et al (1997) also describes poverty from 5standpoints. They regarded it as the denial suffered by persons in the areas of nutritional needs, healthcare needs, educational and literacy needs, economic needs and social needs. Economic denial relates to lack of access to a steady income, factors of production, economic assets, finances and a job. Social denial was attributed to deprivation full engaging in social, political and economic activities. Ogunsakin \& Fawehinmi (2017) categorized poverty into four types. The first was regarded as Absolute abject or chronic. This type of poverty is not just relative to basic needs but also reaches far into the mind of the sufferer. This is most commonly found in Africa where people are bereaved of ideas and are poor even in the state of their mind in addition to lacking access to basic necessities of life such as food, clothes and shelter. The second type is the relative poverty. This is described in relation to the standard of living obtainable elsewhere in the world. It entails comparing the standard of living of people in different locations within a society and hence one will be able to determine the comparability based on what is being experienced per time. While a person can be said to be in comfort, same condition might be a state of discomfort for another. This is more prominent in comparing standard of living in developed and developing countries. The third being disguise poverty involves situation where individuals or groups are exploring the economic benefits of being in poverty as a way of amassing wealth. This is the situation of some states in Nigeria where groups have continued to sabotage the efforts of government at improving the living standards of people because it will end the economic benefits they are enjoying from the poor conditions of living. This particular type of poverty is often popular where there is a high level of corruption and porosity in the system and it is often terminal. The last type described by Ogunsakin \& Fawehinmi (2017) is the poverty of the mind. This is a situation where a person or individual is not able to be self-content. The person often feels he or she is undermined and is always unsatisfied with what he or she has.

Kama and Adigun (2013) noted in their study that the scourge of poverty in Nigeria continues to increase despite reports showing that the economy was growing at an average of 7\% between 2009 and 2011. The recent recovery from recession also reflects a growing economy but all of this is not reflective on the populace who are still largely unemployed and living at a very poor standards. However, from the achievements and transformations of developed economies and the recent emerging Asian tigers, it is obvious that poverty can be alleviated to a minimal level if the government is able to focus on areas and activities that improve people's livelihood. Poverty is usually synonymous or linked with financial exclusion whereby people due to their social and economic disabilities are directly and indirectly excluded from formal financial services. As a result of this financial exclusion, they are left with the option of engaging informal finance providers. Hariharan \& Marktanner (2012) opined that financial inclusion is a huge prerequisite for economic growth and they based it on its ability to enhance capital creation, financial sector savings and intermediation.

\section{Linking the two Concepts}

Numerous financial reforms had been done in Nigeria to encourage banks to extend financial services including credit to individuals and small group entrepreneurs in order to increase economic activity levels and ultimately reduce poverty. Despite all the efforts including the various innovative ideas and efforts of the CBN and commercial Banks, just a very small percentage of the country's population are still included 
within the financial system. The Nigerian banking industry as at May 2018 has 22 Deposit Money Banks with over 6,000 branch networks spread around the country (CBN, 2018). Over $40 \%$ of these numbers are concentrated in few states. Also, there are about 19,000 ATMs and over 15,000 POS terminals currently deployed by Banks across the country (CBN, 2014), but with a high concentration of these numbers in these few states. Banks have grown and continue to grow in their infrastructural expansion and innovation, but these facilities are highly underutilized despite the large bankable population that the country has.CBN (2012) as noted by Fadun (2014) posited that Nigerian Bank branches serve an average of 3,882 customers. This in comparison with Kenya with 3,722 customers served per branch given its size and Tanzania's 8,595 customer served per branch is an indication of the underutilization of banking services in Nigeria. Fadun (2014) identified three major barriers to financial services as accessibility, eligibility and financial literacy. He suggested the need for financial literacy awareness and the introduction of fewer complexes and a general-purpose type of services with less ambiguity that can be easily understood by all. Part of the efforts of the CBN is the introduction and constant revision of the categorization of customers into tiers with the least type of customer needing just his/her passport to be eligible to access financial services.

The pursuit of financial inclusive strategies is very important in the fight against poverty. It increases access to avenues through which they can save their funds. Such funds can then be channeled to investment activities thereby leading to improved standard of living, enhance free flow of funds, create more jobs and thereby reduce poverty (Okoye et al, 2017). Financial inclusion allows the poor to engage in both physical and human investment activities thereby increase economic activities in poor communities. Miller (2005) identified that through financial intermediation function, banks are able to reduce transaction costs, facilitate investment, and also avail capital needed for investment in new technologies. However, poor people in developing nations often do not have access to formal financial services and hence are unable to enjoy these economic transformation functions of financial institutions. Richter (2011) noted that the level of financial services available in a particular location is a function of the the geographical sphere of the area, the language of the people, their literacy level and also the economic environment for production and investment opportunities. These factors are highly constrained in the rural areas where there is high investment risks and community hostility premised on high level of illiteracy. As such the residence of these areas are left to depend on the services of informal institutions to enjoy basic financial services prominent among which is short term credits and group contributions popularly known as 'ajo' or 'esusu'.

\section{Theoretical Framework}

This study infers from Gerschenkron's Great Spurt Theory which states that for a less developed economy to transit from the traditional level of economic backwardness to a modern industrial economy, it will need a sharp break from the past or a great spurt of industrialization (Balami, 2006). The theory posited that the process of industrialization is dependent on the level of backwardness in each economy. The theory recognizes that all economies were once backward and have over time shaped into different classes based on the level of industrialization. He classified economies into four categories which include very backward, backward, moderate and advance economies. The theory further asserts that that development and transition of a very backward economy will start from the activities in factories, involvement of banks and policy support of government respectively. Although the theory suggests the application of capital intensive technique in the production process in order to spark the great spurt, it very well recognizes the importance of a sound financial system that is able to capture all the economic activities of the people within the economy for the economic growth and improved standards of living being desired to be achieved. Although some authors believe that the theory is might not work for an economy with a large labor size like Nigeria as it discourages the use of labor which in turn might increase the level of unemployment and may likely reduce the standard of living of some people (Okoye et al, 2017).Theoretical findings from other studies found that all advanced economies with high standard of living have strong positive relationship with the three factors of the activities in factories, involvement of banks and policy support of government respectively as postulated in the great spurt theory (Demirguc-Kunt, 2008). Several other studies also noted a positive relationship between financial deepening and income while a negative relationship was found between the former and poverty level (Beck, Demirguc-kunt \& Levine, 2007). 
The nature of the study is purely longitudinal as it employs time series analysis on data obtained from secondary sources between the periods of 1992 and 2016. The study employed yearly data on selected variables as obtained from statistical bulletins of CBN, National Bureau of Statistics reports, World Bank reports and the financial reports of NDIC within the period covered. The ordinary least square regression technique was adopted for the study. Financial inclusion was adopted as the independent variable and was proxied by the average current and savings account balances of Deposit Money Banks (CASA), average number of customers of Deposit Money Banks (NBC), average cost of loans to the agricultural sector of the economy from Deposit Money Banks (CoL), average loan size to the agricultural sector of the economy from Deposit Money Banks (LS), and number of Deposit Money Bank branches in the country (DMBbr) in the period covered. The above variables were adopted as proxies for financial inclusion as the purpose of this study is to examine financial inclusion which is explained to be the level of accessibility of financial services to people who were previously denied. An increase in any of the above variable is an indication of a change in the level of financial inclusion in the country and hence the factors are a good representation of the concept.

The author also adopted Poverty as the dependent variable and proxied it as the average Per capita income (PI) as measured in the years reviewed in the model built for the study. A major goal of financial inclusion has been the reduction of the level of poverty in the country and this study is an attempt to test the validity of this goal. Per capital income is an indicator of the people's standard of living and the overall well-being of the society. An increase in per capita income will mean that living standards have improved and hence poverty level has reduced and vice versa. The variable is a good representation of the country's poverty level as expressed in the study.

The econometric model developed form the above is as expressed below:

$P v t=f(F I)$

Where Pvt is proxied by PI

FI is proxied by CASA, NCB, CoL, LS, and DMBbr

The model is re-expressed as:

$\mathrm{PI}=\mathrm{f}(\mathrm{CASA}, \mathrm{NBC}, \mathrm{CoL}, \mathrm{LS}, \mathrm{DMBbr})$

And expanded as:

$\mathrm{PI}=\alpha_{0}+\alpha_{1} \mathrm{CASA}_{1}+\alpha_{2} \mathrm{NCB}_{2}+\alpha_{3} \mathrm{CoL}_{3}+\alpha_{4} \mathrm{LS}_{4}+\alpha_{5} \mathrm{DMBbr}_{5}+\mu \mathrm{t}$.

The data obtained were processed using the e-views statistical package while results were evaluated using rule of thumb.

\section{Result And Findings}

Model: PI=f (CASA, NBC, CoL, LS, DMBbr)

Dependent Variable $=$ PI

Method: Ordinary Least Square Regression

Sample: 1992-2016 (No. of Observation 25)

Regression Analysis Result

\begin{tabular}{|l|l|l|l|l|}
\hline Variable & Coefficient & Std. Error & t-statistics & Sig. \\
\hline Constant & 413.6543 & 128.45123 & 14.6512 & 0.0326 \\
\hline CASA & 0.41432 & 0.5213426 & 2.43288 & 0.0000 \\
\hline NBC & 0.23598 & 0.0943253 & 4.52851 & 0.0007 \\
\hline CoL & -0.35433 & -2.7689321 & 1.85643 & 0.0003 \\
\hline
\end{tabular}




\begin{tabular}{|l|l|l|l|l|}
\hline LS & 0.18987 & 1.5432145 & 1.70984 & 0.0026 \\
\hline DMBbr & 0.09765 & 2.3214556 & 1.51226 & 0.0005 \\
\hline \hline Durbin-Watson Stat & 1.875431 & & Mean dependent var. & 856.3688 \\
\hline Log Likelihood & 187.2243 & & S.D dependent var. & 402.1134 \\
\hline Sum Squared Residual & 17654780 & & Akaike info Criterion & 24.62131 \\
\hline S.E of regression & 543.167 & & Schwarz Citerion & 22.11345 \\
\hline R-Squared & 0.897142 & & F-Statistics & 24.4324 \\
\hline Adj. R-Squared & 0.743217 & & Prob (F-Statistics) & 0.0002 \\
\hline \hline \multicolumn{2}{|l|}{ Source: E-view Output. 1992-2016 Survey Data } & & \\
\hline
\end{tabular}

Based on the result obtained from the regression analysis as seen above, it is observed that average current and savings account balances of Deposit Money Banks (CASA), average number of customers of Deposit Money Banks (NBC), average loan size to the agricultural sector of the economy from Deposit Money Banks (LS) all have a strong and significant positive relationship with the per capital income (PI) level in the country. It is also observed that although number of Deposit Money Bank branches in the country (DMBbr) also has a positive relationship with per capita income (PI), the impact is insignificant. Average cost of loans to the agricultural sector of the economy from Deposit Money Banks $(\mathrm{CoL})$ on the other hand has a strong and significant negative impact on Par Capital Income (PI). The R-squared and Adj. R-square values both show that over $89 \%$ and $74 \%$ (respectively) of the variation in the dependent variable are explained by the independent variables. This confirms the model to be a good fit. While the Durbin-Watson statistics shows that there is no multicolinearity between the independent variables at the level of 1.875 , the F-Statistics estimate of 24.4324 confirms the statistical significance of the regression analysis done.

\section{Findings, Conclusion and Recommendations}

The study was done to evaluate the concept of financial inclusion as a catalyst for poverty alleviation in Nigeria drawing reference from financial inclusive activities between 1992 and 2016. The result of the study revealed that financial inclusion activities such as on-boarding of new customers, current and savings account mobilization and advancement of loans to the agricultural sector all have significant positive relationship with per capital income of the people hence can reduce poverty. This is because the higher their par capital income, the lower their level of poverty. The study in line with other studies supported the view that there exists a negative relationship between the average cost of loans to the agricultural sector of the economy from Deposit Money Banks. This means that the higher the rate of loans charged by the DMBs on loans extended to the sector, the lower the par capital income of the people and hence an increase in their level of poverty. The financial inclusion factor which is the number of Deposit Money Bank branches had a positive but insignificant impact on par capital income hence the opening of branches by a bank doesn't guarantee that it will affect the income level of the people and hence is indifferent to their poverty level. It can therefore be concluded that financial inclusion can serve as a catalyst for poverty alleviation in Nigeria.

Going by the findings in the study, it is recommended that the government should encourage Banks to continue to take advantage of all the financial inclusion policies of the government in mobilizing funds from the informal sector into the banking system and this can be best done by increasing the number of customers within the financial system. This is not to be done only by pursuing the inclusion of more people but by also ensuring that there is no voluntary or involuntary exit of people from the financial net. The cost of using financial services including interest on loans should also be minimized especially the agricultural sector as this indirectly increases the cost of purchasing food items and hence higher cost of living and lower living standards. Banks are also advised to focus more on the maximization of the capacity of the branches where they operate and should reduce the amount they expend on building branches as it doesn't promote financial inclusiveness neither does it enhances people's standard of living. They can embrace the concepts of agency banking and other innovative ideas such as mobile money, USSD and other virtual services that deliver banking services to people within communities where they do not have presence. This is more efficient, cost effective and will be more penetrative. 
[1] Aduda, J. and Kalunda, E. (2012), 'Financial Inclusion and Financial Sector Stability with reference to Kenya: A review of .literature,' Retrieved from Journal of Applied Finance and Banking.

[2] Ajakaiye, O. (1998), 'Conceptualization of Poverty in Nigeria,' Proceedings of the 7th Annual Conference of the Zonal Research Units, Central Bank of Nigeria, Makurdi, June, 8-12, 2008.

[3] Ajide, F.M. (2014), 'Financial inclusion and rural poverty reduction: Evidence from Nigeria', Retrieved from https://www.researchgate.net/publication/304624192

[4] Aku, P.S. et al, (1997), 'Perspective on Poverty Alleviation Strategies in Nigeria,' Proceedings of the Nigerian Economic Society Annual Conference on Poverty Alleviation in Nigeria 1997.

[5] Ardic O. P. et al, (2011), 'Access to Financial Services and the Financial Inclusion Agenda around the World - A Cross- Country Analysis with a New Data Set' - A publication of the World Bank Financial and Private Sector Development Consultative Group to Assist the Poor January 2011.

[6] Balami, D. H. (2006), 'Macroeconomic Theory and Practice,' University of Maiduguri Centre for Distance Learning, Retrieved from www.unimaid.edu.ng/oer/...oer/.../ECO\%20202\%20MACROECONOMICS\%20I.pdf.

[7] Beck, T., Demirguc-Kunt, A. \& Levine, R. (2004). 'Finance, inequality and poverty: cross-country evidence,' World Bank Policy Research Working Paper 3338. Retrieved on 17th march, 2018 from www.aeaweb.org/assa/2005/0108_0800_0302.pdf.

[8] Central Bank of Nigeria (2012), 'National Financial Inclusion Strategy' Summary Report, Central Bank of Nigeria, Abuja

[9] Central Bank of Nigeria (2017), 2016 Statistical Bulletin: Financial Statistics, Retrieved from http://www.cbn.gov.ng/documents/statbulletin.asp

[10] Cyn-Young, P. and Rogelio, V.M. (2015), 'Financial Inclusion, poverty and Income Inequality in Developing Asia,' ADB Economic Working Paper Series no 426.

[11] Demirguc-Kunt, A. (2008), 'Finance for All? Policies and Pitfalls in Expanding Access' World Bank Report, 2085. Retrieved from www.worldbankreportarchive.com.

[12] Essegbey, G. O. \& Frempong, G. K. (2011). 'Creating space for innovation - the case of mobile telephony in MSEs in Ghana,' Technovation, 31(12), 679-688

[13] Fadun, S.O. (2014), 'Financial Inclusion, Tool for Poverty Alleviation and Income Redistribution in Developing Countries: Evidences from Nigeria,' Academic Research International Vol. 5(3) May 2014.

[14] Gordon, O. (2005), 'Indicators of Poverty and Hunger' - Presented at the Expert Group Meeting on Youth Development Indicators, United Nations Headquarters, New York between $12^{\text {th }}-14^{\text {th }}$ December 2005.

[15] Hariharan, G. \& Marktanner, M. (2012), 'The Growth Potential from Financial Inclusion' being a draft submitted for Atlanta Fed/GSU International Development Economics Workshop. Retrieved from https://www.frbatlanta.org/-/media/documents/news/conferences/2012/intldevelopment/Hariharan.pdf.

[16] Irving Fisher Committee on Central Bank Statistics, (2018), 'The role of data in supporting financial inclusion policy'. IFC Bulletin No 47

[17] Kama, U. \& Adigun, M. (2013), 'Financial inclusion in Nigeria: Issues and challenges' CBN Occasional Paper No. 45, 2013.

[18] Khan H. R. (2011), 'Financial Inclusion and Financial Stability: Are they two sides of the same Coin?' Proceedings of the Indian Bankers Association and Indian Overseas Bank, Chennai, November 4, 2011. Retrieved from http://www.bis.org/ review/r111229f.pdf.

[19] Khavul, S. \& Bruton G. D. (2012), 'Harnessing Innovation for Change: Sustainability and Poverty in Developing Countries'. Retrieved from Journal of Management studies

[20] Latifee, H.I. (2003), 'Microcredit and Poverty Reduction,' A Paper presented at the International Conference on Poverty Reduction through Microfinance, held at Ceylan Intercontinental Hotel, Taksim, Turkey June 9-10, 2003.

[21] Leeladhar, V. (2005), 'Taking banking services to the common man- Financial inclusion' Commemorative Lecture by Deputy Governor Reserve Bank of India on December 2, 2005 at Ernakulam. Retrieved from www.bis.org/review/r051214e.pdf

[22] Leyshon, A. \& Thrift, N. (1995), 'Geographies of Financial Exclusion - Financial Abandonment in Britain and the United-States,' Transactions of the Institute of British Geographers, 20, 312-341. 
[23] Martinez M.V. (2011), 'The Political Economy of Increased Financial Access,' A Thesis Submitted in partial fulfillment of the requirement of the Degree of Master of Public Policy to the faculty of the Graduate School of Arts and Social Sciences of Georgetown University.

[24] Mbutor, M. O \& Ibrahim A. U. (2013), 'The impact of financial inclusion on monetary policy in

[25] Nigeria,' Retrieved from the Journal of Economics and International Finance.

[26] McKinsey Global Institute (2014), 'Nigeria's Renewal: Delivering Inclusive Growth in Africa's largest Economy,' Retrieved from http://www.mckinsey.com/mgi,

[27] Migap, J., Okwanya, I. and Ojeka, G. (2015), 'Financial Inclusion for Inclusive Growth: The Nigerian Perspective,' Retrieved from International Journal of Information Technology and Business Management.

[28] Miller, C. (2005), 'Global perspectives in rural finance and poverty alleviation'. Paper presented at the 4th AFRACA Microfinance forum: Lessons learnt in micro and rural finance service provision in Africa. Kampala. Retrieved from www.ruralfinance.org/.../1132063684235_AFRACA_Global_Perspect

[29] Mohan, R. (2006), 'Economic growth, financial deepening and financial Inclusion'. A Paper presented at the Annual Bankers' Conference 2006, at Hyderabad on Nov 3, 2006.

[30] National Bureau of Statistics (2017), 'Selected Banking Sector Data' Retrieved from www.nigerianstat.gov.ng/download/

[31] Nkwede, F. (2015), 'Financial Inclusion and Economic Growth in Africa: Insight from Nigeria,' Retrieved from European Journal of Business and Management.

[32] Ogunsakin, S. \& Fawehinmi, F. O. (2017), 'Financial Inclusion as an Effective Policy Tool of Poverty Alleviation: A Case of Ekiti State. Retrieved from IOSR Journal of Economics and Finance.

[33] Okafor, F. O. (2011), 'Fifty Years of Banking Sector Reforms in Nigeria (1960-2010): Past LessonsFuture Imperatives,' Retrieved from First Bank Research Chair in Banking and Finance. Nnamdi Azikiwe University Akwa, Nigeria.

[34] Okaro, C. (2016), 'Financial Inclusion and Nigerian Economy,' Retrieved from Journal of Policy and Development Studies (JPDS).

[35] Okoye et. al, (2016), 'Financial Inclusion: A Panacea for Balanced Economic Development,' Presented at the 28th IBIMA Conference: Theme -Vision 2020: Innovation Management, Development Sustainability, and Competitive Economic Growth.

[36] Prahalad, C. K. \& Hammond, A. (2002), 'Serving the World's Poor. Profitably,' Harvard Business School Review. Retrieved from Harvard Business School's September 2002 Issue.

[37] Rangarajan Committee, (2008), 'Report of the Committee on Financial Inclusion,' Retrieved from https://www.sidbi.in/files/Rangarajan-Commitee-report-on-Financial-Inclusion.pdf

[38] Richter, P. (2011), 'Rural policy brief,' International Labour Office Publication, Retrieved from www.ilo.org.

[39] Sanusi, L. S. (2011), 'Financial Inclusion for Accelerated Micro, Small and Medium Enterprises Development: The Nigerian Perspective,' Paper presented at the 2011 Annual Microfinance and Entrepreneurship Awards.

[40] Sarma, M. and Pais, J. (2008), 'Financial Inclusion and Development: A Cross Country Analysis.' Retrieved from www.microfinancegateway.org $/ \mathrm{p} / \mathrm{site} / \mathrm{m} / \mathrm{template.rc/1.9.50826/}$

[41] Thorsten, B. (2016), 'Financial Inclusion - measuring progress and progress in measuring' Retrieved from https://www.imf.org/external/np/seminars/eng/2016/statsforum/pdf/beck_paper

[42] Umar, B. (2011), 'The Islamic Finance Option to Financial Inclusion'. Paper presented at a workshop on Microfinance and financial inclusion in Nigeria.

[43] Trade and development report (2014), Presented during the United Nations Conference on Trade and Development held at the United Nation's Offices in New York and Geneva in 2014.

[44] World Bank (2015), Global Financial Development Report 2014: Financial Inclusion. Washington, DC.http://data.worldbank.org/datacatalog/financial_inclusion

[45] World Bank (2016), Global Financial Development Report 2015: Financial Inclusion. Washington, DC. http://data.worldbank.org/datacatalog/financial_inclusion

[46] World Bank (2017), Global Financial Development Report 2016: Financial Inclusion. Washington, DC.http://data.worldbank.org/datacatalog/financial_inclusion 